\title{
Bienvenidos Nuevos Editores!
}

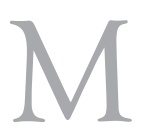

antendo atual o espírito dinâmico da RBR, inovações em seu corpo editorial têm sido uma prioridade, não só atendendo às solicitações do SciELO, mas principalmente buscando o aperfeiçoamento da revista e sua maior visibilidade na América Latina e no Caribe.

Objetivando, cada vez mais, difundir a alta qualidade e credibilidade da ciência que se pratica em nosso país, iniciamos a expansão e internacionalização de nosso conselho editorial, buscando diluir a regionalização do núcleo bandeirante (São Paulo, capital e interior). Por isso, agradecemos o aceite entusiasmado dos novos membros do comitê editorial.

A partir desta edição, a seção Atualização em Reumatologia passou a contar com a preciosa colaboração do colega Boris A. Cruz, que nos presenteia com uma excelente revisão da literatura recente sobre aspectos clínicos, fisiopatológicos e terapêuticos da doença de Behçet ${ }^{1}$, tema também abordado na seção Relatos de Caso, em que dois diferentes grupos ${ }^{2,3}$ nos oferecem suas apreciações sobre o uso de infliximabe como arsenal terapêutico da doença de Behçet refratária.

Atendendo à grande demanda de comunicação entre nossos colaboradores, à crescente necessidade de divulgarmos

\section{REFERÊNCIAS}

1. Cruz BA: Atualização em doença de Behçet. Rev Bras Reumatol 45: 84-9, 2005.

2. Souza AWS, Pileggi P, Hachbarth ET: Tratamento com infliximabe da doença de Behçet ativa. Rev Bras Reumatol 45: 91-3, 2005.

3. Freitas SS, Dionello CF, Rezende LS, Serratto VA, Baumle ACB, Rachid Filho A: Infliximabe no tratamento de uveíte posterior casos inusitados - que nem sempre cabem no escopo formal dos relatos de casos -, reflexões críticas sobre experiências semelhantes ou diversas de matérias publicadas, ou ainda ao compartilhamento de vivências pessoais nas diversas áreas que abrangem nossa vibrante especialidade, estamos revitalizando a sessão Cartas aos Editores, motivo por que convidamos e estimulamos nossos leitores e prezados colegas a expressarem suas opiniões. Para iniciarmos essa nova fase, nada mais revigorante do que compartilhar o ponto de vista de um dos mais atuantes revisores, o Dr. Marco Antonio P. de Carvalho, com sua pungente opinião a respeito do formato de artigos submetidos para publicação, enviados por jovens colaboradores, sob o auspício de seus experientes preceptores ${ }^{4}$. Ainda nessa seção, contamos com a exposição de fundamentos para a utilização da equoterapia como recurso terapêutico adicional na espondilite anquilosante ${ }^{5}$.

Compartilhem do prazer de divulgar a ciência nacional, enviando sugestões.

Lais V. Lage e Roger A. LeVy Editores da RBR

refratária em paciente com doença de Behçet. Rev Bras Reumatol 45: 94-7, 2005.

4. Carvalho MAP: Carta aos editores. Rev Bras Reumatol 45(2): XIX, 2005.

5. Dias MNA, Fortes CEA, Dias RP: Atuação da equoterapia na espondilite anquilosante. Rev Bras Reumatol 45: XIII-XIV, 2005. 